\title{
TETŐCSERÉP KÉSZÍTŐ MÜHELY MEZŐHEGYES HATÁRÁBAN (BÉKÉS MEGYE)
}

\section{Bíró GYÖNGYVÉR ${ }^{1}$}

Magyar Régészet 9. évf. (2020), 4. szám, pp. 30-38. doi: https://doi.org/10.36245/mr.2020.4.5

A tanulmány egy mezöhegyesi Árpád-kori lelöhelyröl számol be, ahol egy érdekes építmény maradványa látott napvilágot. A téglából épített objektum kialakitása, illetve a benne és körülötte talált jelentös menynyiségü rontott tetöcserép alapján tetöcserép-égetö kemenceként funkcionált az építmény, melyhez hasonlót viszonylag keveset ismerünk. A Mezöhegyesen lelt tetöcserepek különlegesnek számítanak a magyarországi régészeti anyagban, párhuzamaikat különböző franciaországi épületkerámiák, valamint az egresi monostor újabban feltárt leletei között találtuk meg, ami egy érdekes kapcsolatrendszert vetít elénk.

\section{RÉGÉSZETI KUTATÁS MEZŐHEGYESEN}

Békés megye déli részén, Mezőhegyesen, a település északi határában Kerekes György helytörténész és múzeumbarát fémkeresős révén vált ismertté egy Árpád-kori lelőhely, melyet jelenleg Mezőhegyes-88-as tábla néven ismer a kutatás (1. kép). A település és a hozzá tartozó temető területe enyhén kiemelkedik a környezetéből, a legmagasabb pont a központi rész, ahol az egykori templom sejthető (ld. a Második Kato-

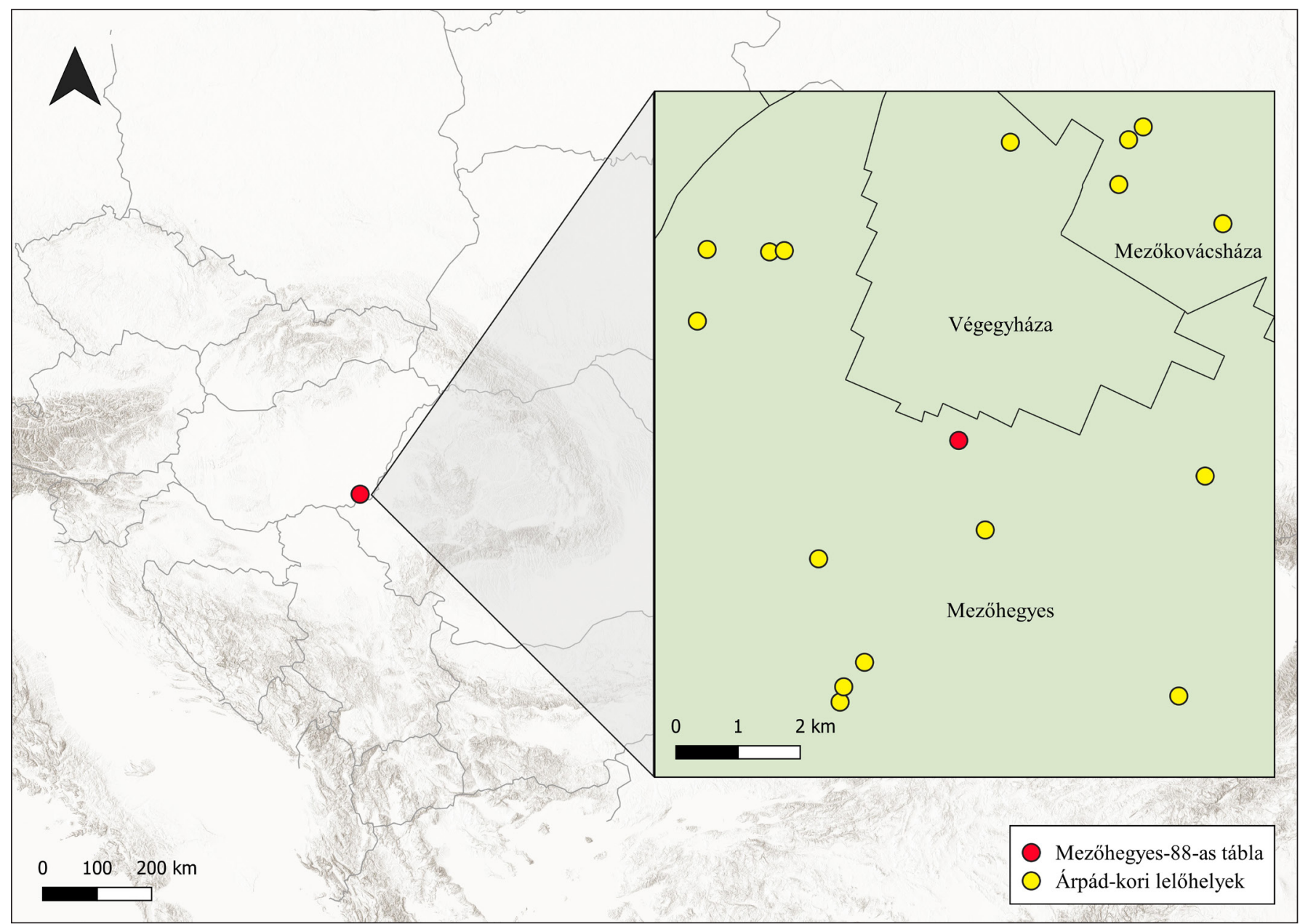

1. kép. A mezöhegyesi lelöhely és az 5 km-es környezetében ismert Árpád-kori lelöhelyek (a térkép alapja: Esri, Airbus DS, USGS, NGA, NASA, CGIAR, N Robinson, NCEAS, NLS, OS, NMA, Geodatastyrelsen, Rijkswaterstaat, GSA, Geoland, FEMA, Intermap and the GIS user community; (C) OpenStreetMap közremüködök) 
Bíró Gyöngyvér • Tetőcserép készitö mühely Mezöhegyes határában (Békés megye)

nai Felmérés térképét). A terület érdekes képet mutat az első katonai felmérésen, ugyanis a térképen látható dủlőutak egy korábbi úthálózat nyomait örizhetik, amelyek épp az adott lelöhelynél érnek össze egy csomópontban (ld. az Első Katonai Felmérés térképét). Nagyjából 130 évvel ezelött alakították ki az Élővízföcsatorna itt futó ágát (То́тн, 1969, 120), melyet keresztülhúztak az Árpád-kori temetkezési helyen, így a csatorna partfalában láthatóvá váltak az emberi maradványok. A temetötől észak-északnyugatra településre utaló Árpád-kori kerámiatöredékek, III. Béla uralkodására (1172-1196) datálható rézpénzek, valamint egy téglaépítmény maradványai (B épület) kerültek elő a korábbi kutatások során (2. kép). A csatorna használata és kotrása, illetve a vadállomány átgázolásai miatt a temető csatorna menti szakasza folyamatosan pusztul, ezért 2017-ben mentő feltárást végeztünk az orosházi Nagy Gyula Területi Múzeum égisze alatt, melynek keretében a temető nyugati szélét, egy, a temetkezéseknél korábbi árkot és egy égetőkemencét tártunk fel a hozzá tartozó hamusgödörrel (3-4. kép). 2019-ben a múzeum és a Szegedi Tudományegyetem Régészeti Tanszéke közötti együttmüködés keretében újabb mentö ásatást végeztünk, amely során a temető további része és az árok folytatása látott napvilágot.

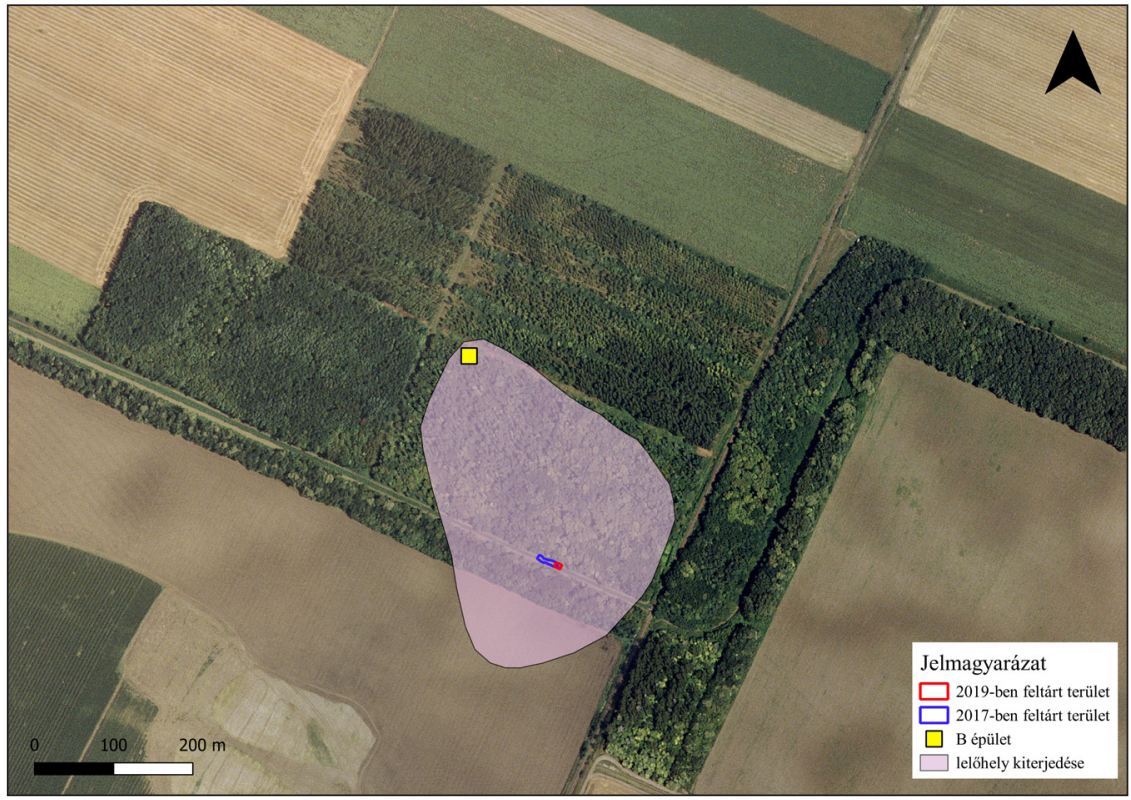

2. kép. Mezőhegyes-88-as tábla lelöhely elhelyezkedése (az ortofotó forrása: Lechner Tudásközpont Nonprofit Kft.)

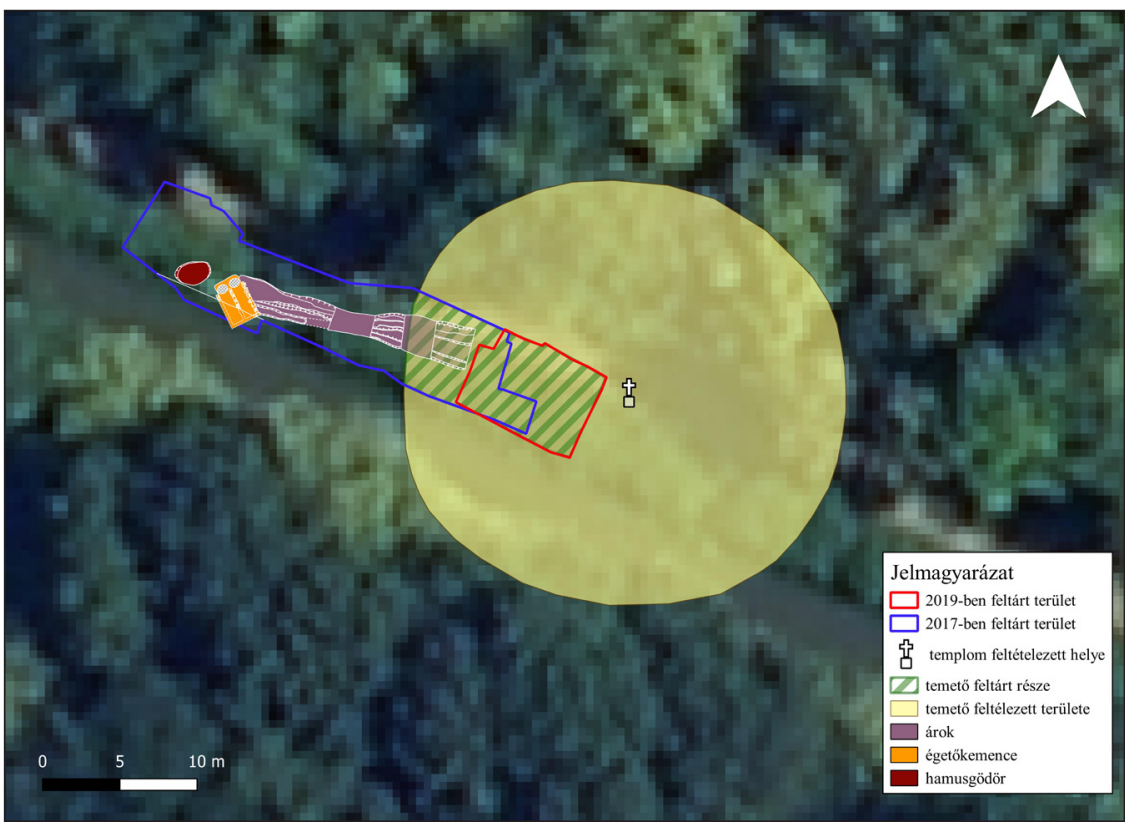

3. kép. Az eddig feltárt terület és a templom körüli temető feltételezett kiterjedése (az ortofotó forrása: Lechner Tudásközpont Nonprofit Kft.)

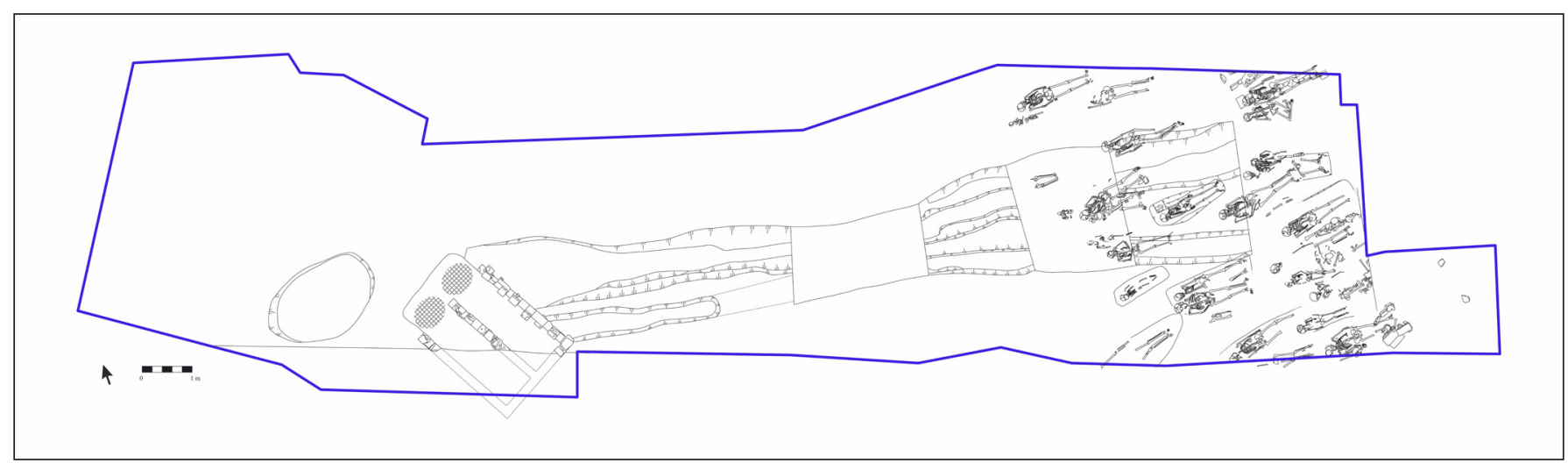


Bíró Gyöngyvér • Tetöcserép készitö mühely Mezöhegyes határában (Békés megye)

\section{TEMPLOM KÖRÜLI TEMETÖ - TEMPLOM NÉLKÜL?}

Eddig 92 sírt, valamint 38, emberi maradványok, illetve részben tégla- és tetőcserép-töredékek alkotta objektumot tártunk fel. Az elhunytakat lepelbe csavarva vagy koporsóba téve temették el, és szinte minden esetben háton, nyújtott testhelyzetben feküdtek, karjaik testük mellett kinyújtva vagy medencéjükre hajtva helyezkedtek el. A temetőben gyakoriak voltak a szuperpozíciók, több sírt is megbolygattak az újabb temetkezések során, a korábbi sírban nyugvó földi maradványait pedig arrébb húzva, egy kupacba téve temették vissza. Leletanyagként csupán néhány viseleti elem (karikaékszerek, övcsat), halotti obulusként adott érme (12. századi anonim denárok), a halotti lepel összefogását szolgáló gombostü, illetve a koporsókhoz tartozó vasalás és szög került elő (5. kép). A sírokból származó leletek alapján a környéken élők a 12. században biztosan használták a most tárgyalt temetkezési helyet, de a lelöhely keltezése a további kutatás során még lefelé és felfelé is módosulhat. Több alkalommal a sírt keretező vagy az elhunyt felett/mellett elhelyezett téglákat és téglatöredékeket figyelhettünk meg, néhány esetben pedig rontott, olykor összeolvadt tetőcserép-töredékek is előfordultak ezek között. Habár magát az egyházi épületet még nem találtuk meg, létezése az említett jelenségek alapján is valószínűsíthető. Az ásatások során fokozatosan délkelet felé haladva tapasztalhattuk, hogy a temetkezések sürüsödnek, egyre több az építőanyag-törmelék, s egyre több a sírok közötti szuperpozíció. Ezek alapján feltételezzük, hogy már nem járhatunk messze az egykori templomtól, melynek építőanyagát helyben állíthatták elő - ahogy erre a 2017-ben feltárt égetőkemence, illetve az épületkerámiák anyagvizsgálatának eredménye is utal (KREITER et al., 2018).

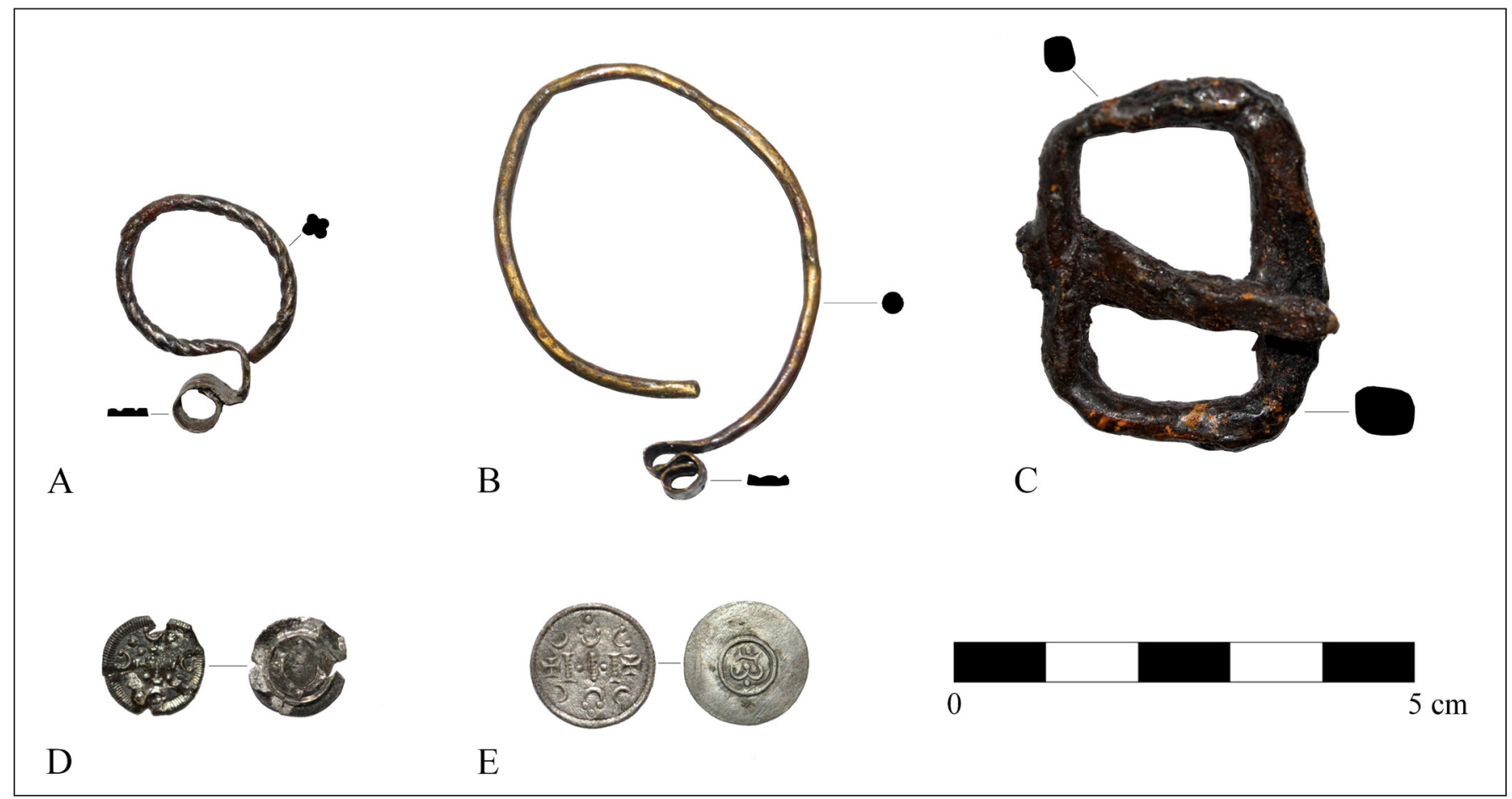

5. kép. Válogatás a temetöböl származó leletekböl, A-B: karikaékszerek; C: vascsat; D-E: 12. századi anonim denárok

\section{A MEZŐHEGYESI TETŐCSERÉP-ÉGETŐ KEMENCE ÉS TERMÉKEI}

\section{Az égetökemence}

A habarccsal rakott téglákból emelt, nagyjából téglalap alaprajzú építmény közvetlenül a mai csatorna partján helyezkedett el, emiatt déli fele elpusztult a csatorna kialakítása és kotrása során. A kemence hátsó falának indítását még épp megfigyelhettük, így lehetséges a teljes alapterület rekonstruálása. Az égetőkemence kb. $2 \times 3$ m-es és két tüzcsatornás kialakítású volt (6. kép). A kemencét közvetlenül a sárga agyagos altalajon építették fel, vagyis az egykori járószint alatt alakították ki azt a területet, ahol a tetőcserepek kiégetése zajlott. Az építményből a három hosszanti, egymással párhuzamos falszakasz maradt meg - az északkeleti 
Bíró Gyöngyvér • Tetöcserép készitö mühely Mezöhegyes határában (Békés megye)

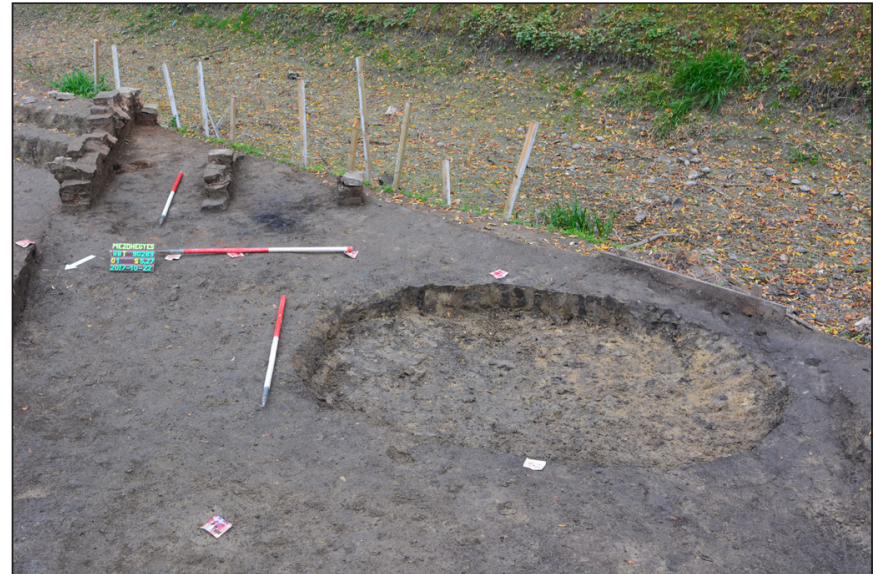

6. kép. Ásatási fotó a mezőhegyesi égetőkemencéröl és a hozzá tartozó hamusgödörröl

fal $240 \mathrm{~cm}$, a középső $126 \mathrm{~cm}$, a délnyugati $41 \mathrm{~cm}$ hosszan őrződött meg, az első esetében még 5-7 téglasor volt eredeti helyzetében. A kemence alja 10 $\mathrm{cm}$ vastagon átégett, vörösesbarna, kemény réteget alkotott. A tüzteret boltívek választották el a felső égetőtértől, amire az északkeleti falmaradvány esetében minden második tégla befelé, a középső fal felé döntött pozíciója utalt. A kemencéhez tartozott egy tőle nagyjából $80 \mathrm{~cm}$-re északnyugatra lévő, $2 \times 1,5$ m-es, ovális alakú hamusgödör is, melynek betöltését a tetőcserép készítő tevékenységből származó hamus, faszenes törmelék és sok apró cserépszilánk alkotta. Az egykori munkaterületet tetőcserépből- és kisebb részben téglatöredékekből álló törmelékréteg fedte. A kemence építőanyagát annak használata után valószínüleg elbányászták, s részben talán épp a sírok sírépítményeiben használták fel, ahogy erre néhány használt (habarcsos) példány is utal.

Habár a címben és helyenként a szövegben is a mühely terminust használjuk, fontos hangsúlyozni, hogy jelenleg csak az égetőkemence, a hamusgödör és a rontott példányok utalnak az egykori ipari tevékenységre, a cserepek előkészítésére és ideiglenes elhelyezésére szolgáló épület - vagyis tényleges mühelyépület - egyelöre nem ismert a lelöhely területén.

\section{A mezöhegyesi tetöcserepek}

A kemencéből és környezetéből származó valamennyi tetőcserép törött, egy részük egyértelmüen rontott - rosszul kiégett, szürke-lila-zöld színü, megrepedt és felpüffedt felületü, légbuborékos szövetü - példány, egész cserepet ezidáig még nem találtunk. A többszáz töredék alapján négy alaptípust különíthetünk el a mezőhegyesi termékek között (7. kép).

Az 1. típus nagyméretü, téglalap alakú, felső részének egyik oldalán bütyök, másik oldalán lyuk kapott helyet, jobb és bal oldalas verzió is elöfordul, mérete $32 \times 21 \times 1,5 \mathrm{~cm}$. Ez a típus van jelen a legnagyobb számban a mezőhegyesi anyagban (7. kép A). A 2. típus valamivel kisebb méretü, trapéz alakú, felső részének egyik oldalán bütyök, másik oldalán lyuk található, van jobb és bal oldalas változata is, mérete $16,7 \times 13-16 \times 2,2-2,5 \mathrm{~cm}$ (7. kép $B$ ). A 3. típus nagyméretü, trapéz formájú, egy-egy kicsi lyukkal a felső és az alsó végén, de lyuk nélküli formában is előfordul, mérete $30,5 \times 5-14,5 \times 1,7-1,8 \mathrm{~cm}$ (7. kép C). A 4. típus kúpcserép, hagyma alakú dísszel, pár példányon világos színü, zöldesfehér árnyalatú máz nyomaival, mérete $18,5 \times 12,5 \times 2 \mathrm{~cm}$, a díszek mérete 5,6-6×2-3 cm (7. kép D).

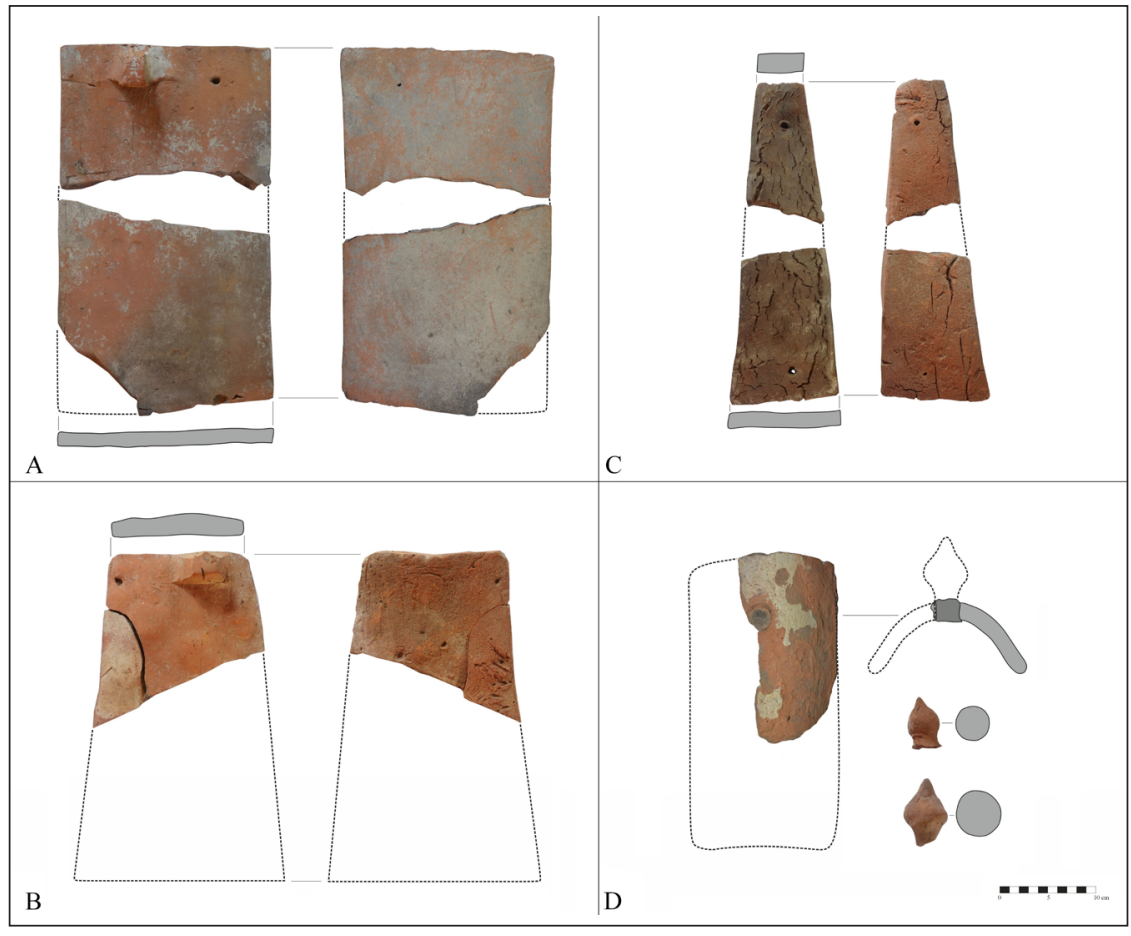

7. kép. A mezöhegyesi tetöcserepek típusai, A: 1. tipus; B: 2. típus; C: 3. típus; D: 4. típus 
Bíró Gyöngyvér • Tetöcserép készitő mühely Mezöhegyes határában (Békés megye)

Az 1. típust sorokba rendezve használhatták a tetőfedésre úgy, hogy a felső sor alsó vége fedte az alatta lévő sor felső, átlyukasztott részét, mivel a lécre támaszkodó bütyök mellett a lyukon keresztül szöggel is rögzítették a cserepeket (VIOLLET-LE-Duc, 1868, 328-329). A 2. és a 3. típus szolgálhatott a sorvégek vagy sarkok lezárására, míg a 4. típus zárhatta le a cserepek összefutását a tetögerincen. Ezzel függhet össze, hogy az 1. típustól a 4. felé haladva egyre kevesebb ismert belölük - de természetesen a templom feltárása még árnyalhatja a képet.

\section{A MEZŐHEGYESI ÉGETŐKEMENCE ÉS A TETŐCSEREPEK KELTEZÉSE}

Az Európában ismert, különböző épületkerámiák (tégla, tetőcserép, padlólap) előállítására szolgáló égetőkemencék között több, a mezőhegyesihez hasonló objektum ismert Nyugat- és Közép-Európában, melyeket általában a 13-15. századra kelteznek. Az égetőkemencék a legtöbb esetben föld alá mélyítettek voltak és két tüzcsatornával rendelkeztek (EAMES, 1961, 139; JAKAB, 2008, 359) - ahogy a mezőhegyesi is. Azonban ezek funkciója olykor kérdéses, mivel nem mindig találnak benne a termék típusára utaló egyértelmü leletet, keltező értékü tárgyak híján pedig néha a pontosabb datálásuk sem lehetséges. Szerencsés körülmény a mezőhegyesi égetökemence esetében, hogy a kemencét beborító törmelékrétegben a jelentős mennyiségü tetőcserép mellett Árpád-kori kerámiatöredékeket, a hasonló korú leletekkel keltezhető sírokban pedig rontott tetőcserepet is találtunk, ami alátámasztja, hogy a tetőcserép készítő mühely és a temető használata egyaránt az Árpád-kor közepe tájára tehető. A korábbi kutatások alapján (JAKAB, 2011) hazánk területén nem ismerünk ilyen korai tetőcserép-égető kemencét.

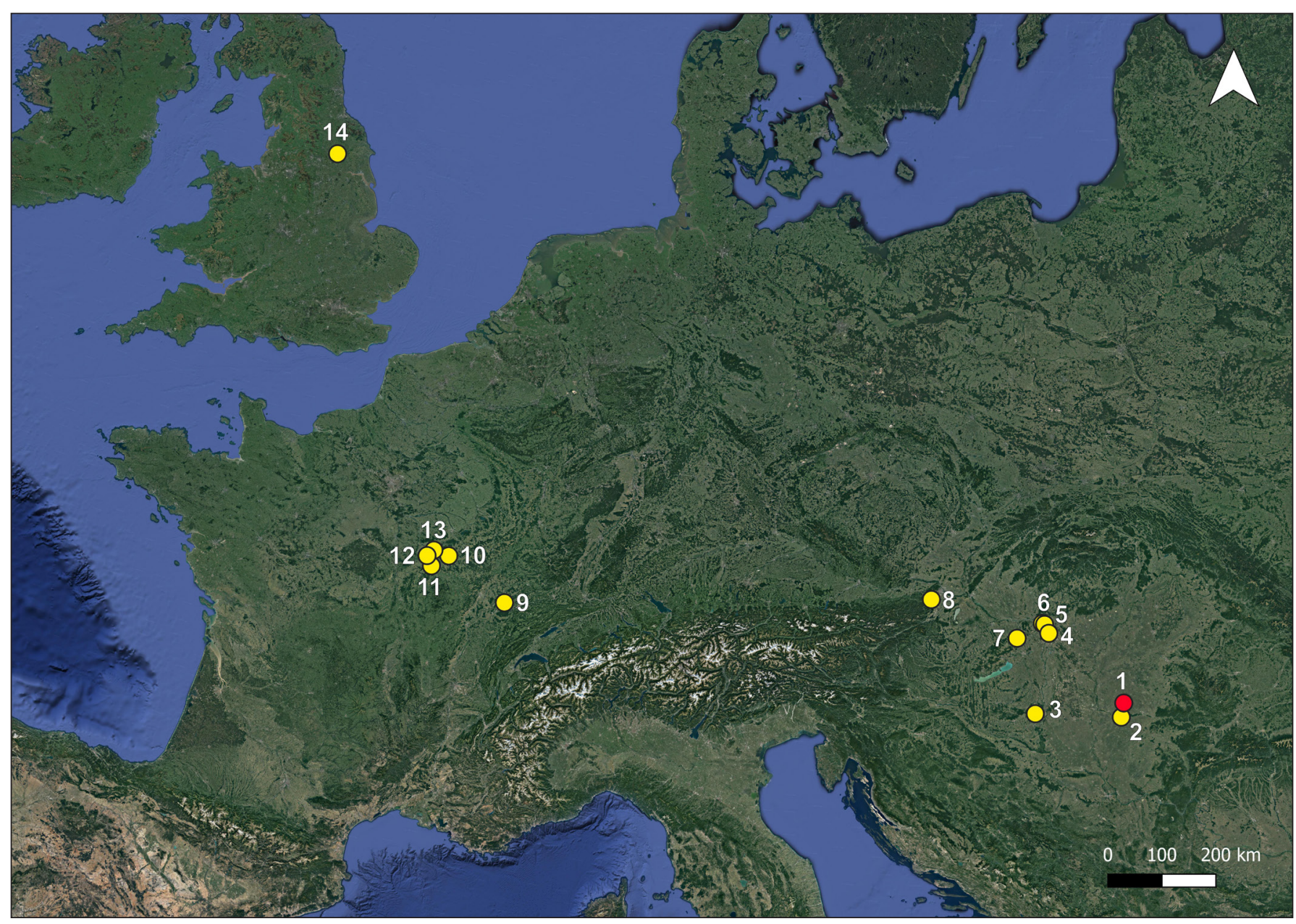

8. kép. A cikkben emlitett magyarországi és külföldi kolostoros helyek, illetve lelöhelyek, 1. Mezöhegyes-88-as tábla, 2. Egres (Igriș, Románia), 3. Cikádor, 4. Margit-sziget, 5. Pomáz-Nagykovácsi, 6. Pilis, 7. Vértesszentkereszt,

8. Heiligenkreuz (Ausztria), 9. Acey (Franciaország), 10. Quincy (Franciaország), 11. Vermenton (Franciaország), 12. Auxerre (Franciaország), 13. Pontigny (Franciaország), 14. York (Egyesült Királyság) (a térkép alapja: Google) 
Bíró Gyöngyvér • Tetöcserép készitö mühely Mezöhegyes határában (Békés megye)

A magyarországi középkori tetőcserepek között kúpcserép, hódfarkú, s olykor téglalap alakú formák is előfordulnak, de a közlemények nem mindig térnek ki az alakra vagy a tárgy pontosabb keltezésére. Az általunk ismert tetőcserepek legkorábbi példányai a vértesszentkereszti apátság esetében a 12-16. századra (KozÁK, 1965, 85), a pilisi ciszterci apátságnál feltehetően a 13. századra (Holl, 2000, 17, 48), a Margit-szigeti domonkos kolostornál pedig a 13. század második fele és a 16. század eleje közötti időszakra datálhatók (KÁDÁR, 2012, 15). A többi, hazánk területén talált középkori, kora újkori tetőcserép 14-16. századi, s általában királyi központokban, városokban, mezővárosokban, valamint különböző szerzetesrendi környezetben, illetve egyházi épületeknél bukkannak fel (Bíró, 2019, 29), de a mezőhegyesiekkel formai kialakításban és méretben azonos típusokat eddig nem találtunk köztük. A külföldi - elsősorban a franciaországi - régészeti anyagban azonban több párhuzam is említhető (8. kép). A mezőhegyesi 1. típus pontos analógiája mind méret, mind forma tekintetében a Pontigny-i ciszterci apátság Pont-T4 cserepe (AumArd et al., 2019, 20, fig. 3). Ugyanakkor az Auxerre-i székesegyház Set-D5 (Aumard et al., 2019, 22, fig. 4) és a vermentoni templom Ver-T3a típusa is hasonló kialakítást mutat (AumARD et al., 2019, 24, fig. 5). A termolumineszcens mérés alapján ezek keltezése: Pont-T4: 1020-1180, Set-D5: 1110-1230, VerT3a: 895-1095 (Aumard et al., 2019, 29, fig. 10). Az említett Pontigny-i példányhoz hasonló 12. századi típus (Type 4) ismert a Quincy-i ciszterci apátságból is (AumARD, 2009). A Henri gróf cserepének nevezett cserép is az 1. típussal rokon, legkorábbi példányait a 13. századra datálják (VIOLLET-LE-Duc, 1868, 326). A 2. típushoz hasonló trapéz alakú tetőcserép ismert Auxerre-böl (Set-B2), annyi eltéréssel, hogy a bütyök középen helyezkedik el, két lyuk található alatta és a külső felülete mázas (AuMARD et al., 2016, 186, fig. 152). Auxerre esetében a 4. típushoz hasonló 12-14. századi kúpcserepeket is találunk, melyeket egy vagy két dísszel láttak el, s olykor mázzal dekoráltak, ahogy Vermentonban is előfordulnak egy-egy dísszel, illetve mázzal ellátott példányok (AUMARD \& SAPIN, 2017). A párhuzamok alapján a mezőhegyesi cserepek esetében - az ásatás során megfigyelt jelenségeket és a feltárt leleteket is figyelembe véve - a 12. századi keltezés látszik elfogadhatónak.

Az egyházi épület még tovább pontosíthatja majd a lelőhely korát, de az már most is bizonyos, hogy mind a temetkezési hely, mind az égetőkemence használatban volt a 12. század folyamán.

\section{KITEKINTÉS - A MEZÖHEGYESI MÜHELY KAPCSOLATRENDSZERE}

Mivel a mezőhegyesi mühelyben készített tetőcserepek pontos analógiái a Pontigny-i ciszterci apátsághoz, illetve több esetben más, a ciszterci rendhez köthetö épülethez vezettek, felmerült a kérdés, hogy összefüggésbe hozható-e a tárgytípus mezőhegyesi jelenléte az említett renddel? Ebből a szempontból fontos kiemelni azt a körülményt, hogy a most ismertetett lelőhelytől légvonalban 23 km-re található az egresi ciszterci monostor. Egres (Igriş, Románia) monostorát III. Béla király alapította 1179-ben, anyaapátsága pedig épp az a Pontigny volt (RupP, 1876, 68; BÁCSATYAI, 2015, 267), ahonnan a párhuzamok is ismertek. Ezek alapján feltételeztük, hogy valamiféle kapcsolat állhatott fenn az egyelöre névtelen mezőhegyesi település és temploma, valamint az egresi ciszterci monostor között. A hipotézis tisztázása céljából 2019 nyarán kollegáimmal ellátogattunk a Bánsági Múzeum és a Pázmány Péter Katolikus Egyetem Régészettudományi Intézetének egresi feltárására. ${ }^{2}$ Egresen nagy mennyiségben kerültek elő tetőcserepek, melyek között a mezőhegyesi példányokkal méretben és kialakításban teljesen megegyező darabok is szerepeltek, ami különösen a mezőhegyesi 1. és 4. típus esetében volt szembetünő. Ahogyan a cikádori és a pilisi monostoroknál nyomon követhető volt az anyaapátság - Heiligenkreuz (Ausztria), illetve Acey (Franciaország) - mühelyének tevékenysége (VALTER, 2009, 131, 144-145), ugyanígy Egres esetében is kimutatható a Pontigny-hez füződő viszony. Az áttekintett egresi anyaghoz képest eltérés csak abban mutatkozott, hogy a mezőhegyesi tetőcserepek homogénebb képet mutatnak, mint az egresi példányok. A monostor építése 1187-ben fejeződött be (RUPP, 1876, 69), majd a tatárjárást követően megújították (TÂNASE et al., 2017, 230), így elképzelhető, hogy az egyébként azonos cseréptípusok kicsit eltérő variációi a monostor építési

2 Köszönetünket fejezzük ki Daniela Tănase, Major Balázs és Langó Péter régészek felé, hogy az ásatás és a leletek megtekintésére lehetőséget adtak. 
Bíró Gyöngyvér • Tetöcserép készitö mühely Mezöhegyes határában (Békés megye)

periódusaival vagy a különböző stílusban dolgozó mesterek közremüködésével magyarázhatók, de ennek eldöntését az egresi anyag kiértékelése teheti majd lehetővé. Ugyanakkor a mezőhegyesi tetőcserepek egyöntetüsége talán épp az azokat előállító egység kisebb méretére (kevesebb mester jelenlétére) vagy nem túl hosszú használati idejére utalhat. Egyelöre nem lehet biztosan megállapítani, hogy pontosan mely időszakban használhatták a mezőhegyesi kemencét. Amennyiben elfogadjuk az egresi monostorral való összefüggést, leghamarabb a monostor 1179-es alapítását követően létesülhetett. Ennek látszólag ellentmondanak a mezőhegyesi sírokban talált 12. századi anonim denárok, amelyek között ennél korábbra datálható példány is akad, de ezek uralkodóhoz kötése nem mindig bizonyos, az érmék a verési idejükhöz képest később is a temetkezésbe kerülhettek, illetve lehetséges, hogy a már használatban lévő temető templomát látták el (utólag?) cseréptetővel. Utóbbi csupán egy feltevés, a tetőcserép-égető kemence működési idejének pontosabb meghatározásához még további kutatás szükségeltetik.

Az Egyesült Királyságban található lelöhelyek esetében az ipari tevékenységet végző egységeket - így az épületkerámiát előállító mühelyeket - a termelés célja és módja, a készítő személye, illetve a mühely elhelyezkedése alapján több csoportba sorolta a korábbi kutatás. Jelen ismereteink alapján a mezőhegyesi mühely feltehetően nem egy vándorló/időszakos, hanem egy letelepedett, ún. házon belüli termelés helyszíne lehetett, ami a szerzetesrendhez kötődött, s ami elsősorban a kemencét müködtető közösség számára állított elö tetőcserepeket (STOPFORD, 1992, 344, 348). Az ebbe a csoportba tartozó lelöhelyekről ismert kemencék általában kis méretüek és igényes kialakításúak, valamint általában csak egyetlen terméket készítettek (STOPFORD, 1992, 357).

Az ipari tevékenység, illetve az ebben is leképeződő kapcsolatrendszer, ami az egyes apátságok, valamint ezek környezete között állt fenn, több helyszín vonatkozásában világosan kirajzolódik. Már az első ciszterci alapítású monostor, Cikádor esetében is megtalálható azon járólapok előfutára, amelyeket a pilisi apátság a 14. század 60-as éveitől kezdődően müködő épületkerámia készítő mühelye állított elő. Utóbbiban nem csupán a rend egyházainak ellátására, de mások - elsősorban a közvetlen környezetük - számára is termeltek (HoLl, 2000, 62-65). Hasonló kapcsolat mutatható ki York (Egyesült Királyság) esetében is, ahol olyan mozaikpadló elemek kerültek elő, amelyek a ciszterciekhez köthetők (McСoмISH, 2015, 31, Plate 28). Az említett pilisi ciszterci apátság többféle ipari tevékenységet végzett, amire a majorságához (grangia) tartozó, Pomáz-Nagykovácsi lelőhelyen feltárt mühelyépületek is utalnak (LASZLovszKy \& STARK, 2017, 241). A majorságot a korábbi Árpád-kori templom köré építették ki, ami a továbbiakban kápolnaként funkcionált (LASZLOVSZKY et al., 2014, 8). Több mühelyépületet és kemencét is kialakítottak, amelyekben az üveggyártás nyomait lehetett megfigyelni. Az ipari tevékenység során speciális kerámia elemeket is alkalmaztak: különböző téglákat állítottak elő a kemencék felépítéséhez, olvasztótégelyeket az üveg olvasztásához, és egyéb kerámiaeszközöket az üveg készítéséhez, formálásához (LASZLOVSZKY \& STARK, 2017, 243-257). Ahogy a pilisi apátság épületkerámiái, úgy az üvegtermékek esetében is egy hasonló piaci régió látszik körvonalazódni (LASZLOVSZKY \& STARK, 2017, 261).

A fentebbieket figyelembe véve, a régészeti leletek és a történeti adatok alapján valószínűnek látjuk az Egres és a közeli mezőhegyesi település között fennálló kapcsolatot. Talán nem alaptalan a feltevés, miszerint utóbbi a ciszterciek birtokának részét képezhette, esetleg a monostor majorságaként működhetett. Ezt szem elött tartva nem csupán a mezőhegyesi templom, de a B épület is figyelmet érdemel a jövőben.

\section{KÖSZÖNETNYILVÁNÍTÁS}

A feltárásban közremüködtek a Nagy Gyula Területi Múzeum munkatársai, családtagjaik és barátaik, a Szegedi Tudományegyetem Régészeti Tanszékének hallgatói, továbbá a Kozma Ferenc Mezögazdasági Szakképzö Iskola és Kollégium diákjai. A geodéziai felmérést az Archeoline Kft., a fémtárgyak restaurálását Lengyel Boglárka végezte. Munkájukat itt is köszönöm! 
Bíró Gyöngyvér • Tetöcserép készitö mühely Mezöhegyes határában (Békés megye)

AJÁNLOTT IRODALOM

Jakab, A. (2008). Égetőkemencék az európai régészeti anyagban. A nyíregyházi Jósa András Múzeum Évkönyve 50, 357-366.

Kádár, J. (2012). A magyarországi tetőcserepek fajtái. In Herczig B. (szerk.), Tetőcserepek és téglák (pp. 5-82). Jeles téglák, jeles emlékeink 6. Baj: Monarchia BTE.

Valter, I. (2009). A középkori magyar ciszterci monostorok alaprajzi és építészeti sajátosságai. In Guitman, B. (szerk.), A ciszterci rend Magyarországon és Közép-Európában (pp. 127-145). Piliscsaba: Pázmány Péter Katolikus Egyetem Bölcsészettudományi Kar.

\section{FELHASZNÁLT IRODALOM}

Aumard, S. \& Sapin, C. (2017). Matériaux et archéologie du bâti en Bourgogne : quels enjeux pour l'histoire de la construction? Elöadás felvétel. https://www.youtube.com/watch? $\mathrm{v}=\mathrm{OMVLc} 2 \mathrm{BuIQE} \& \mathrm{t}=654 \mathrm{~s}$ (Letöltés: 2018.08.22.)

Aumard, S. (2009). Les tuiles médiévales de l'abbaye cistercienne de Quincy (Tanlay, Yonne), 2007-2008. Bulletin du centre d'études médiévales d'Auxerre, BUCEMA [En ligne] 13, 97-98. https://doi.org/10.4000/ $\underline{\text { cem.11309 }}$

Aumard, S., Ben Amara, A., Büttner, S., Cantin, N., Lanos, P., Dufresne, P., Zink, A. \& Porto, É. (2016). La couverture monumentale en chantier. Les cathédrales d'Auxerre et Sens d'aprés les données archéologiques, archéométriques et historiques. In F. Duperroy \& Y. Desmet (eds.), Les couvertures médiévales. Images et techniques (pp. 181-193). Namur, Études et Documents, Monuments et Sites 14. Namur: Institut du Patrimoine Wallon, Service Publications. https://hal.archives-ouvertes.fr/hal-01961883

Aumard, S., Ben Amara, A., Büttner, S., Cantin, N., Zink, A. \& Porto, É. (2019). Les premiéres tuiles plates en Auxerrois (XIIe-XIIIe siécles): approche typologique et archéométique. In F. Thuillier, Les terres cuites architecturales en France du Moyen-Âge à l'époque contemporaine : recherches sur les tuileries et les productions tuilières (pp. 15-38). Mergoil: Archéologie Moderne Contemporaine. https://hal.archivesouvertes.fr/hal-02093829

Bácsatyai, D. (2015). Az egresi ciszterci monostor korai történetének kérdései. Századok 149 (2), $263-299$.

Bíró, Gy. (2019). Árpád-kori tetőcserép-égető kemence a mezőhegyesi határban. In Herczig B. (szerk.), Tetöcserepek és téglák (pp. 25-31). Jeles téglák, jeles emlékeink 6. Baj: Monarchia BTE.

Eames, E. (1961). A thirteenth-century tile kiln site at North Grange, Meaux, Beverley, Yorkshire. Medieval Archaeology 5 (1,) 137-168. https://doi.org/10.1080/00766097.1961.11735650

Holl, I. (2000). Funde aus dem Zisterzienserkloster von Pilis. Varia Archaeologica Hungarica 11. Budapest: Archäologisches Institut der UAW.

Jakab, A. (2008). Égetőkemencék az európai régészeti anyagban. A nyíregyházi Jósa András Múzeum Évkönyve 50, 357-366. 
Bíró Gyöngyvér • Tetöcserép készitö mühely Mezöhegyes határában (Békés megye)

Jakab, A. (2011). Téglaégető kemencék a középkori Magyarországon. A nyíregyházi Jósa András Múzeum Évkönyve 53, 131-160.

Kádár, J. (2012). A magyarországi tetőcserepek fajtái. In Herczig B. (szerk.), Tetőcserepek és téglák (pp. 5-82). Jeles téglák, jeles emlékeink 6. Baj: Monarchia BTE.

Kozák, É. (1965). 143. Vértesszentkereszt. In Sz. Burger A. (szerk.), Az 1964. év régészeti kutatásai (pp. 83-83). Régészeti Füzetek 18. Budapest: Magyar Nemzeti Múzeum \& Történeti Múzeum.

Kreiter, A., Skoda, P., Kristály F. \& Kelemen, É. (2018). Mezőhegyes 88-as tábla lelőhely Árpád-kori téglaés tetöcserép töredékeinek petrográfiai vizsgálata. In Bíró Gy., Katona-Kiss A. \& Rózsa Z. (szerk.), Fémek a földböl I (pp. 77-85). Orosháza és vidéke múltjából 19. Orosháza: Orosháza Város Önkormányzat Nagy Gyula Területi Múzeuma.

Laszlovszky, J., Mérai, D., Szabó, B. \& Vargha, M. (2014). A pilisi „üvegtemplom”. Magyar Régészet 3 (4) [2014 tél], 1-10.

Laszlovszky, J. \& Stark, K. (2017). Medieval glass production at Pomáz-Nagykovácsi: The finds and heritage interpretation of an archaeological site. Annual of Medieval Studies at CEU 23, 239-264.

McComish, J. M. (2015). A Guide To Ceramic Building Materials. An Isight Report. York Archaeological Trust. Finding the Future. York: York Archaeological Trust for Excavation and Research.

Rupp, J. (1876). Magyarország helyrajzi története fö tekintettel az egyházi intézetekre. Vol. 3. Budapest: A Magyar Tudományos Akadémia Történelmi Bizottsága.

Stopford, J. (1992). The organisation of the medieval tile industry. Oxford Journal of Archaeology 11 (3), 341-363.

Tânase, D., Bertók, G., Kocsis, A. \& Major, B. (2017). The location of Egres Cistercian monastery - Igriş (Timiş County), in the light of recent geophysical research. Ziridava Studia Archaeologica 31, 229-327.

Tóth, I. (1969). Mezőhegyes, szorosabban a mezőhegyesi állami gazdaság története. Kézirat.

Valter, I. (2009). A középkori magyar ciszterci monostorok alaprajzi és építészeti sajátosságai. In Guitman B. (szerk.), A ciszterci rend Magyarországon és Közép-Európában (pp. 127-145). Piliscsaba: Pázmány Péter Katolikus Egyetem Bölcsészettudományi Kar.

Viollet-le-Duc, E. (1868). Dictionnaire raisonné de l'architecture française du XIe au XVIe siècle. Tome 9. Paris: Morel A. 